\title{
PENURUNAN MUTU SENYAWA ANTIOKSIDAN DAN KADAR AIR TERHADAP MASA SIMPAN PERMEN HISAP EKSTRAK DAUN CIPLUKAN (Physalis angulata Linn.)
}

\section{DECREASING THE QUALITY OF ANTIOXIDANT COMPOUNDS AND WATER CONTENT TO THE SHELF-LIFE OF CIPLUKAN (Physalis angulata Linn.) LEAF EXTRACT LOZENGES CANDY}

\author{
Rohmah Luthfiyanti, Ade Chandra Iwansyah, Nitra Yustia Pamungkas, \\ Agus Triyono \\ Pusat Penelitian Teknologi Tepat Guna, Lembaga Ilmu Pengetahuan Indonesia \\ K.S. Tubun No. 5 Subang, 41211, Jawa Barat, Indonesia \\ Email: rohmahluthfiyanti.78@gmail.com
}

Diterima : 04-07-2019

Direvisi : 27-09-2019

Disetujui : 14-01-2020

\begin{abstract}
ABSTRAK
Permen hisap ekstrak daun ciplukan (Physalis angulata Linn) sebagai pangan fungsional yang mengandung senyawa antioksidan alami rentan mengalami kerusakan, sehingga tujuan dari penelitian ini adalah menentukan umur simpan permen hisap ekstrak daun ciplukan berdasarkan laju perubahan kandungan senyawa antioksidan yaitu flavonoid dan polifenol serta laju perubahan kadar air. Metode yang digunakan untuk analisis kandungan senyawa flavonoid yaitu metode Kolorimetri menggunakan spektrofotometri UV-VIS pada panjang gelombang $431 \mathrm{~nm}$. Analisis kandungan senyawa polifenol dengan metode Folin-Ciocalteu menggunakan spektofotometri UV-VIS pada panjang gelombang 765 $\mathrm{nm}$. Kadar air dianalisis dengan metode Gravimetri. Metode perhitungan umur simpan menggunakan metode Arrhenius. Hasil penelitian menunjukan bahwa dalam suhu ruang $\left(28^{\circ} \mathrm{C}\right)$ terjadi perubahan kandungan senyawa flavonoid, polifenol serta perubahan kadar air. Kandungan senyawa flavonoid dan polifenol mengalami penurunan dengan nilai energi aktivasi pada senyawa flavonoid sebesar 0,8027 $\mathrm{kal} / \mathrm{mol}$ dan energi aktivasi pada senyawa polifenol sebesar 59,7627 kal/mol sedangkan kadar air dari permen hisap ekstrak daun ciplukan mengalami peningkatan dengan perolehan energi aktivasi sebesar $1,1118 \mathrm{kal} / \mathrm{mol}$. Nilai energi aktivasi dari parameter kadar air digunakan untuk menentukan umur simpan produk karena nilai kadar air mengalami peningkatan sehingga diperoleh regresi linier $=0,5598 x+$ $4,5013\left(R^{2}=0,9905\right)$. Hasil perhitungan umur simpan berdasarkan parameter kadar air didapatkan bahwa umur simpan permen hisap ekstrak daun ciplukan pada suhu ruang $\left(28^{\circ} \mathrm{C}\right)$ yaitu selama 11 bulan.
\end{abstract}

Kata kunci: ciplukan, permen hisap, antioksidan, umur simpan, kadar air

\section{ABSTRACT}

Ciplukan (Physalis angulata Linn) leaf extract Lozenges, as a functional food, containing natural antioxidant compounds that are susceptible to damage. This research aimed was to determine the shelf life of Ciplukan lozenges leaf extract based on the rate of change in the content of antioxidant compounds flavonoids, polyphenols, and the quality of change of the water content. The method used to analyze flavonoids' content is the Colorimetric method. The Folin-Ciocalteu method was used to analyze the polyphenol compound's content using UV-VIS spectrophotometry at a wavelength of $765 \mathrm{~nm}$. Water content was analyzed using the Gravimetric method. The method was used to estimate the shelf life is the Arrhenius method. The analysis of shelf life at room temperature at $28^{\circ} \mathrm{C}$ from 4-time points showed that the content of flavonoids, polyphenols, and water content had been changed. The content of flavonoids and polyphenols has decreased with the activation energy. Value of flavonoid compounds of $0.8027 \mathrm{cal} / \mathrm{mol}$ and the activation energy of polyphenol compounds of $59.7627 \mathrm{cal} / \mathrm{mol}$ while the water content of ciplukan leaf extract lozenges has increased with the 
acquisition of activation energy of $1.1118 \mathrm{cal} / \mathrm{mol}$. The activation energy value of the water content parameter is used to determine the shelf life of the product. The value of the water content has increased so that linear regression is obtained $y=0.5598 x+4.5013\left(R^{2}=0.9905\right)$. The calculation of shelf life based on water content parameters found that the shelf life of ciplukan leaf extracts lozenges at room temperature $\left(28^{\circ} \mathrm{C}\right)$ for 11 months.

Keywords: ciplukan, lozenges candy, antioxidant, shelf life, water content

\section{PENDAHULUAN}

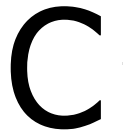

iplukan (Physalis angulata L.) adalah nama sejenis buah kecil, yang ketika masak tertutup oleh perbesaran kelopak bunga. Buah ini juga dikenal dengan berbagai nama daerah seperti cecenetatau cecendet (Sd.), nyurnyuran (Md.), dan kopok-kopokan (BI.).Ciplukan merupakan tumbuhan perdu yang sering digunakan oleh masyarakat Indonesia karena banyak mengandung senyawa fitokimia yang bermanfaat bagi kesehatan tubuh dengan kandungan kimia antara lain glikosida flavonoid, alkaloid, saponin, fisalin, protein, withangulatin A (turunan dari withanolide yang merupakan salah satu jenis steroid) asam falmitat, asam asetat sehingga dapat digunakan sebagai anti-hiperglikemi, antibakteri, antivirus, imunostimulan dan imunosupresan (imunomodulator), antiinflamasi, antioksidan, analgesik, antidiabetes, dan sitotoksik, juga sebagai peluruh air seni (diuretik), menetralkan racun, meredakan batuk, mengaktifkan fungsi kelenjar-kelenjar tubuh dan anti tumor. Saponin yang terkandung dalam daun ciplukan memberikan rasa pahit dan sifat menyejukkan serta berkhasiat sebagai anti tumor dan menghambat pertumbuhan kanker, terutama kanker usus besar. Flavonoid dan polifenol berkhasiat sebagai antioksidan (Rohyani et al, 2015).

Senyawa antioksidan merupakan senyawa pemberi elektron atau reduktan yang mampu menghilangkan, membersihkan, menahan efek radikal bebas dimana antioksidan dapat mencegah reaksi oksidasi yang berlebihan terhadap kerusakan sel beta pankreas sehingga dapat menyebabkan kadar glukosa darah turun (Winarsi, 2007). Perolehan kandungan senyawa antioksidan dalam daun ciplukan dilakukan dengan proses ekstraksi menggunakan etanol $70 \%$ dengan penambahan maltodekstrin sebanyak $9 \%$ sehingga didapatkan hasil ekstrak dengan kandungan senyawa antioksidan yang optimal (Triyono et al, 2019).

Ekstrak daun ciplukan diolah menjadi permen hisap. Permen hisap adalah sediaan padat mengandung satu atau lebih senyawa aktif, umumnya dengan bahan dasar beraroma dan manis, yang dapat membuat permen melarut atau hancur perlahan dalam mulut. Permen hisap umumnya ditujukan untuk mengobati iritasi lokal atau infeksi mulut atau tenggorokan, tetapi dapat juga mengandung bahan aktif yang ditujukan untuk absorbsi sistemik setelah ditelan (Farmakope Indonesia, 2014). Permen hisap ekstrak daun ciplukan mengandung senyawa antioksidan yang rentan mengalami kerusakan akibat panas, cahaya maupun oksigen dan dapat disertai oleh perubahan kadar air, dimana terjadinya penurunan ataupun kenaikan kadar air dapat mempengaruhi jumlah kandungan senyawa metabolit lain dalam bahan pangan tersebut (Damar et al, 2014; Winarno, 2007).

Enam faktor utama yang dapat mengakibatkan terjadinya penurunan mutu atau kerusakan pada produk pangan, yaitu oksigen, uap air, cahaya, mikroorganisme, kompresi atau bantingan, dan bahan kimia toksik atau off flavor. Faktor-faktor tersebut dapat mengakibatkan terjadinya penurunan mutu yang mempengaruhi umursimpan produk, diantaranya seperti oksidasi lipida, kerusakan vitamin, kerusakan protein, perubahan bau, reaksi pencoklatan, perubahan unsur organoleptik, dan kemungkinan terbentuknya racun (Herawati, 2008). Penelitian ini bertujuan untuk menentukan umur simpan dari permen hisap ekstrak daun ciplukan berdasarkan penurunan mutu yang disebabkan dari faktor eksternal. 


\section{METODE PENELITIAN}

\section{Bahan dan Alat Penelitian}

Bahan yang digunakan yaitu permen hisap ekstrak daun ciplukan pada formulasi terpilih, larutan standar kuersetinSigma-Aldrich Chemie Product of India, metanol p.a, $\mathrm{AlCl}_{3}$ $10 \%$, aquadest, natrium asetat $1 \mathrm{M}$, larutan standar asam galat, reagen Folin-Ciocalteau $(1: 10), \mathrm{Na}_{2} \mathrm{CO}_{3} 7,5 \%$. Alat yang digunakan yaitu tabung reaksi, neraca analitik Metteler Toledo AL204, gelas kimia $100 \mathrm{~mL}$, oven, aluminium foil, cawan petri danspektrofotometer Shimadzu UV-VIS 1900 Serial No. AI24256.

\section{Prosedur Penelitian}

\section{Pembuatan Ekstrak Daun Ciplukan}

Daun ciplukan disortasi dengan memisahkan daun ciplukan yang sudah berlubang dan berwarna kekuningan, kemudian dilakukan pencucian dan penirisan. Daun hasil pencucian dipotong untuk mengecilkan ukuran sehingga dapat mengoptimalkan proses ekstraksi maserasi. Ekstraksi maserasi dilakukan selama 24 jam pada suhu $28^{\circ} \mathrm{C}$ dengan pelarut etanol yang telah dikonsentrasikan dengan perbandingan daun dan etanol yaitu 1:10. Hasil maserasi dilakukan penyaringan dengan memisahkan ampas (daun) sehingga didapat ekstrak cair yang kemudian dilakukan penambahan maltodekstrin pada beberapa konsentrasi sebelum dilakukan evaporasi untuk mendapatkan ekstrak kental daun ciplukan pada suhu $50^{\circ} \mathrm{C}$ pada tekanan 60 $\mathrm{cmHg}$.

\section{Pembuatan Permen Hisap Ekstrak Daun Ciplukan}

Ekstrak kental daun ciplukan dilakukan pencampuran dengan aerosil, Avicel PH 101, dan maltodekstrin DE 10-15 sampai didapatkan masa yang homogen. Campuran tersebut, kemudian dilakukan pengayakan basah pada mesh 16 sebelum dilakukan pengeringan pada suhu $40-50^{\circ} \mathrm{C}$ selama kurang lebih 1 jam. Hasil pengeringan dilakukan penghalusan kemudian diayak kembali dengan mesh 60 . Pencampuran terakhir dengan penambahan $\mathrm{Mg}$ stearat, sorbitol atau stevia, dan pappermint lalu dicetak pada ukuran dengan diameter $1 \mathrm{~cm}$ dan tinggi $0,5 \mathrm{~cm}$. Permen hisap ekstrak daun ciplukan yang telah dicetak, dilakukan proses Coating permen dengan penambahan maltodekstrin stevia atau sorbitol, dan pappermint yang telah dilarutkan dengan air panas yang kemudian dikeringkan kembali pada suhu $40-50^{\circ} \mathrm{C}$ selama kurang lebih 1 jam.

\section{Analisis Kuantitatif Flavonoid}

Metode analisis kuantitatif flavonoid yaitu metode Kolorimetri menggunakan spektrofotometri UV-VIS pada panjang gelombang $431 \mathrm{~nm}$ dengan kuersetin sebagai larutan standar (Ahmad et al, 2014).

Pembuatan larutan standar kuersetin. Ditimbang $10 \mathrm{mg}$ baku standar kuersetin dan dilarutkan dalam $10 \mathrm{~mL}$ metanol p.a untuk 1000 ppm, dari larutan standar kuarsetin 1000 ppm, kemudian dipipet $1 \mathrm{~mL}$ dan dilarutkan dalam $10 \mathrm{~mL}$ metanol p.a untuk 100 ppm, kemudian dibuat beberapa konsentrasi 10 ppm, 20 ppm, 30 ppm, 40 ppm, dan 50 ppm. Pada masing-masing konsentrasi larutan standar kuersetin ditambahkan $3 \mathrm{~mL}$ metanol, 0,2 mL $\mathrm{AlCl}_{3} 10 \%, 0,2 \mathrm{~mL}$ kalium asetat $1 \mathrm{M}$, dan di cukupkan dengan aquades sampai $10 \mathrm{~mL}$, kemudian diinkubasi selama 30 menit pada suhu ruang $\left(28^{\circ} \mathrm{C}\right)$. Analisis flavonoid diukur absorbansinya pada spektofotometri UV-Vis dengan panjang gelombang $431 \mathrm{~nm}$. Penetapan kadar flavonoid total pada sampel yaitu:

a. Timbang $100 \mathrm{mg}$ sampel dan dilarutkan dalam $10 \mathrm{~mL}$ metanol.

b. Diambil $1 \mathrm{~mL}$ sampel dan ditambahan $3 \mathrm{~mL}$ metanol, 0,2 $\mathrm{mL} \mathrm{AlCl} 310 \%, 0,2 \mathrm{~mL}$ kalium asetat, dan dicukupkan dengan aquadestilata sampai $10 \mathrm{~mL}$.

c. Simpan selama 30 menit pada tempat gelap dalam suhu ruang $\left(28^{\circ} \mathrm{C}\right)$. 
d. Absorbansinya diukur pada spektrofotometri UV-Vis dengan panjang gelombang $431 \mathrm{~nm}$.

e. Larutan sampel dibuat dalam tiga kali replikasi sehingga kadar flavonoid yang diperoleh sebagai ekuivalen kuersetin.

Prinsip penetapan flavonoid dengan metode Kolorimetri $\mathrm{AlCl}_{3}$ adalah pembentukan kompleks, sehingga terjadi pergeseran panjang gelombang ke arah visible (nampak) yang ditandai dengan larutan menghasilkan warna yang lebih kuning pada panjang gelombang 431 $\mathrm{nm}$. $\mathrm{AlCl}_{3}$ akan bereaksi dengan gugus keto pada $\mathrm{C} 4$ dan gugus $\mathrm{OH}$ pada $\mathrm{C} 3$ dan $\mathrm{C} 5$ pada senyawa flavon atau flavonol membentuk senyawa kompleks yang stabil. Larutan standar kuersetin digunakan karena kuersetin merupakan flavoniod golongan flavonol yang memiliki gugus keto pada atom C4 dan juga gugus hidroksil pada atom C3 dan C5 (Zhu et al, 2009).

\section{Analisis Kuantitatif Polifenol}

Metode analisis kuantitatif polifenol yaitu metode Folin-Ciocalteu menggunakan spektrofotometri UV-VIS pada panjang gelombang $765 \mathrm{~nm}$ dengan asam galat sebagai larutan standar (Pourmorad et al, 2006).

Standar asam galat dibuat dengan variasi konsetrasi 5-125 ppm dan diukur absorbansinya pada panjang gelombang $765 \mathrm{~nm}$. Prosedur pengukuran sampel dilakukan dengan cara menimbang sampel sebanyak $100-150 \mathrm{mg}$ lalu ditambahkan dengan 0,5 ml metanol, 2,5 ml aquadest dan 2,5 ml reagent Folin-Ciocalteau 50\%. Campuran didiamkan selama 5 menit kemudian ditambahkan dengan $2 \mathrm{ml} \mathrm{Na} \mathrm{CO}_{3}$ 7,5\% dan divorteks lalu diinkubasi selama 15 menit pada suhu $45^{\circ} \mathrm{C}$. Absorbansi sampel diukur pada panjang gelombang $765 \mathrm{~nm}$ dengan menggunakan spektrofotometer UV-VIS.

Prinsip metode Folin-Ciocalteu adalah reaksi oksidasi gugus fenolik hidroksil. Pada proses reaksi, gugus fenolik-hidroksil bereaksi dengan pereaksi Folin-Ciocalteu, membentuk kompleks fosfotungstat-fosfomolibdat berwarna biru dengan struktur yang belum diketahui dan dapat dideteksi dengan spektrofotometer pada panjang gelombang $765 \mathrm{~nm}$. Warna biru yang terbentuk akan semakin pekat setara dengan konsentrasi ion fenolat yang terbentuk (Singleton dan Rossi, 1965).

\section{Analisis Kadar Air}

Analsis kadar air menggunakan metode grafimetri. Sampel sebanyak 3-5 gr ditimbang dan dimasukan kedalam cawan yang telah dikeringkan dan diketahui bobotnya, kemudian sampel dan cawan dikeringkan dalam oven suhu $105^{\circ} \mathrm{C}$ selama 3 jam. Cawan didinginkan dan ditimbang, lalu dikeringkan kembali sampai diperoleh bobot konstan (Sudarmadji dan Bambang, 2003).

\section{Uji Penurunan Mutu}

Uji penurunan mutu pada permen hisap ekstrak daun ciplukan dilakukan dengan perlakuan penyimpanan pada suhu ruang $28^{\circ} \mathrm{C}$ dalam keadaan terbuka (tanpa dikemas apapun). Pengamatan dilakukan dengan dua ulangan dan diamati secara berkala pada hari yang telah ditentukan yaitu tiap 4 hari sekali mulai hari ke-0 sampai hari ke-12. Parameter yang dianalisis yaitu kadar air, kadar flavonoid dan kadar polifenol. Dimana saat kadar polifenol dan kadar flavonoid menurun sedangkan kadar air meningkat maka dapat dikatakan kualitas permen hisap ekstrak daun ciplukan menurun (Solihin et al, 2015). Data yang diperoleh dilakukan analisis regresi linier sederhana untuk mengetahui hubungan antara variabel yang diukur dengan lama penyimpanan, persamaannya yaitu :

Dimana :

$$
y=a+b x
$$

$y=$ variabel yang diukur 
$\mathrm{x}=$ umur simpan

$\mathrm{a}=$ nilai variabel yang diukur pada saat mulai disimpan

$\mathrm{b}=$ laju kerusakan $(\mathrm{k})$

Nilai k yang diperoleh dari persamaan regresi diterapkan pada persamaan Arrhenius (Syarif dan Halid, 1992) yaitu :

$$
\begin{gathered}
k=\begin{array}{c}
k o \cdot e-E / R T \\
\text { Atau }
\end{array} \\
\ln k=\ln k o-E / R T
\end{gathered}
$$

Dimana:

$\mathrm{k}=$ konstanta penurunan mutu

ko= konstanta (tidak tergantung pada suhu)

$\mathrm{E}=$ energi aktivasi

$\mathrm{T}=$ suhu mutlak $(\mathrm{C}+273)$

$\mathrm{R}=$ konstanta gas, $1,986 \mathrm{kal} / \mathrm{mol}$

Umur simpan dapat ditentukan dengan persamaan berdasarkan nilai dari atribut mutu yang dianalisis pada hari ke-0 sampai hari ke-t, yaitu (Haryati et al, 2015):

Dimana:

$$
\begin{gathered}
A t=A o+k \cdot t \\
t=\frac{A 0-A t}{k}
\end{gathered}
$$

Ao $=$ Nilai atribut mutu pada awal penyimpanan (hari ke-0)

At $=$ Nilai atribut mutu pada akhir penyimpanan (hari ke-t)

$\mathrm{k}=$ konstanta penurunan mutu

$\mathrm{t}=$ umursimpan produk (hari)

\section{HASIL DAN PEMBAHASAN}

\section{Kandungan Flavonoid dan Polifenol}

Penurunan flavonoid dan polifenol juga dapat terjadi seiring meningkatnya kandungan air dalam permen hisap ekstrak daun ciplukan. Dengan kadar air yang tinggi akan mempercepat pertumbuhan mikroba dan reaksi-reaksi kimia yang bersifat merusak bahan makanan seperti oksidasi maupun hidrolisis, sehingga bahan pangan akan memiliki umur simpan yang pendek (Winaro, 1997).Penurunan kandungan flavonoid dan polifenol selama penyimpanan dapat dilihat pada Tabel. 1.

Tabel 1. Penurunan Kandungan Flavonoid dan Polifenol pada Kondisi Suhu Ruang $\left(28^{\circ} \mathrm{C}\right)$

\begin{tabular}{ccc}
\hline Hari Ke- & $\begin{array}{c}\text { Rata-rata Kadar Flavonoid } \\
\text { (ppm) }\end{array}$ & $\begin{array}{c}\text { Rata-rata Kadar Polifenol } \\
\text { (mg GAE/g Ekstrak) }\end{array}$ \\
\hline 0 & 23,053 & 3464,29 \\
4 & 22,035 & 3278,02 \\
8 & 20,3665 & 3174,42 \\
2 & 18,220 & 3097,59 \\
\hline
\end{tabular}


Data pada Tabel 1. menunjukan, bahwa selama penyimpanan suhu ruang $\left(28^{\circ} \mathrm{C}\right)$ terjadi penurunan nilai kandungan flavonoid. Persamaan regresi untuk kandungan flavonoid permen hisap ekstrak daun ciplukan, yaitu y $=-0,4042 x+23,344\left(R^{2}=0,9761\right)$ berarti konstanta penurunan mutunya (k) 0,4042. Energi aktivasi (Ea) perubahan flavonoidyaitu Ea $=0,4042 \times 1,986(\mathrm{R}) \mathrm{kal} / \mathrm{mol}$ didapatkan Ea sebesar 0,8027 kal $/ \mathrm{mol}$ yang artinya untuk memulai terjadinya perubahan terhadap kandungan flavonoid pada permen hisap ektrak daun ciplukan diperlukan energi sebesar tersebut. Grafik penurunan mutu kandungan flavonoid dapat dilihat pada Gambar 1.

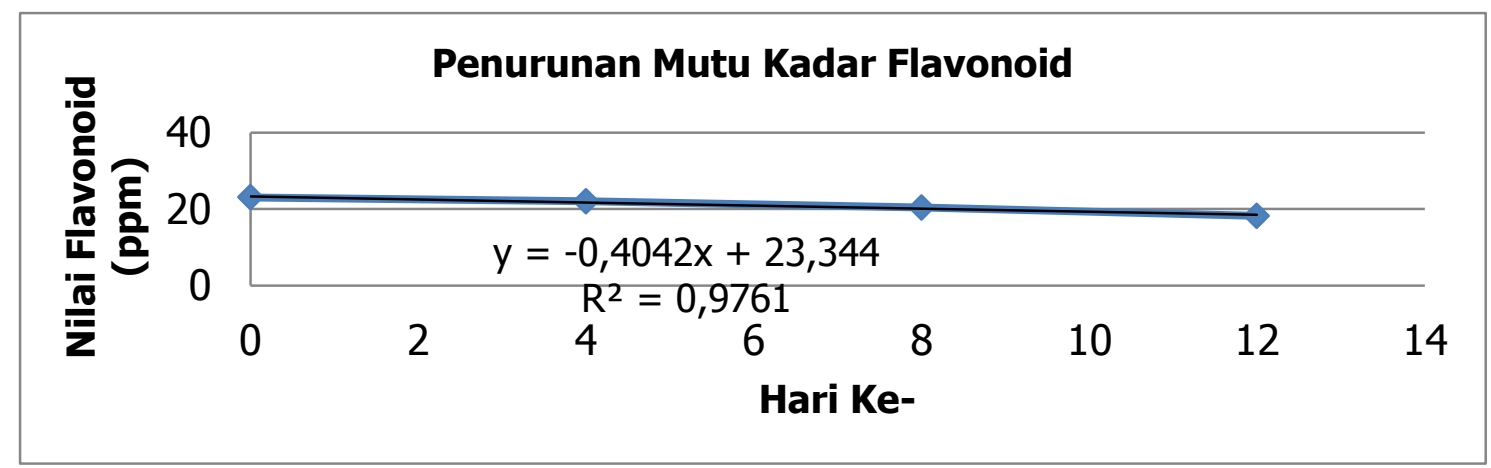

Gambar 1. Grafik Regresi Linier Penurunan Mutu Kandungan Flavonoid

Data pada Tabel 1 menunjukan, bahwa selama penyimpanan suhu ruang terjadi penurunan nilai kadar polifenol. Persamaan regresi untuk kadar polifenol permen hisap ekstrak daun ciplukan, yaituy $=-30,092 x+3434,1\left(R^{2}=0,9583\right)$ berarti konstanta penurunan mutunya (k) 30,092. Energi aktivasi (Ea) perubahan polifenolyaitu Ea $=30,092 \times 1,986(\mathrm{R})$ $\mathrm{kal} / \mathrm{mol}$ didapatkan Ea sebesar59,7627 kal/molyang artinya untuk memulai terjadinya perubahan terhadap kandungan polifenol pada permen hisap ektrak daun ciplukan diperlukan energi sebesar tersebut. Grafik penurunan mutu kandungan polifenol dapat dilihat pada Gambar 2.

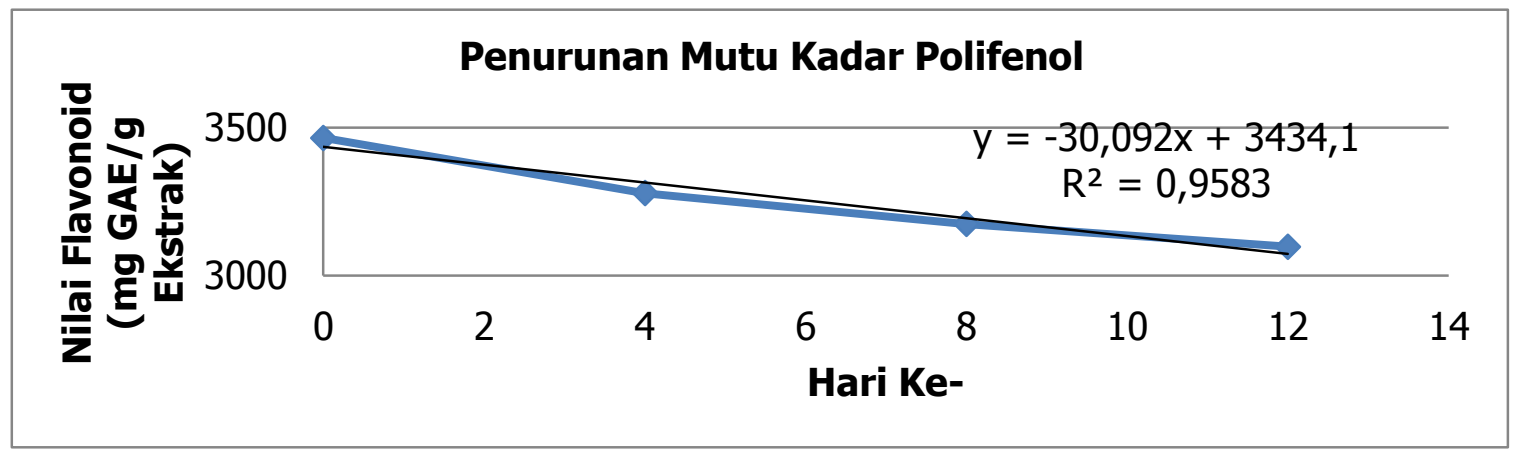

Gambar 2. Grafik Regresi Linier Penurunan Mutu Kandungan Polifenol

Permen hisap ekstrak daun ciplukan merupakan salah satu pengembangan produk pangan terbaru yang diharapkan dapat menjadi suatu pangan fungsional yang praktis untuk membantu pengobatan penyakit diabetes melitus. Ekstrak daun ciplukan yang terdapat dalam permen hisap mengandung senyawa antioksidan flavonoid dan polifenol yang dapat membantu memperbaiki kadar glukosa darah (Fitri et al, 2016; Dewanti et al, 2017). Sebagai antioksidan alami senyawa aktif flavonoid dan polifenol memiliki fungsi dapat mencegah komplikasi atau progresifitas diabetes mellitus dengan cara meredam radikal bebas. Semakin tinggi kandungan flavonoid dan polifenol dalam suatu ekstrak maka, semakin kuat kemampuan ekstrak tersebut meredam radikal bebas (Luh dan Razimin, 2013; Rustiani dan Ariati, 2017; 
ermawan et al, 2018). Permen hisap ekstrak daun ciplukan yang mengandung senyawa antioksidan flavonoid dan polifenol pada umumnya rentan mengalami kerusakan.

Kerusakan Pangan adalah setiap perubahan sifat-sifat fisik, kimiawi, sensorik atau organoleptik yang ditolak oleh konsumen pada bahan pangan yang masih segar ataupun yang telah diolah. Perubahan pada bahan pangan yang menyebabkan menurunnya nilai, dapat dikatakan bahwa bahan pangan atau produk pangan tersebut telah rusak atau membusuk. Perubahan yang nyata terlihat dari perubahan sensorik (penampakan, konsistensi, bau dan rasa), sehingga konsumen menolak. Bahan pangan atau produk pangan yang rusak atau busuk dinyatakan sebagai tidak layak konsumsi atau Unsuitable for Human Consumption (Muchtadi dan Sugiyono, 2013).

Kerusakan pada bahan pangan dibagi menjadi 5 jenis yaitu, kerusakan mikrobiologis, mekanis, fisik, kimia dan biologis. Faktor eksternal yang dapat mempengaruhi laju tingkat kerusakan bahan maupun produk pangan diantaranya, cahaya (sinar matahari), kelembaban udara, oksigen, suhu (pemanasan dan pendinginan), serangga parasit dan tikus, sedangkan faktor internal yang dapat mempengaruhi laju tingkat kerusakan yaitu adanya aktifitas enzim dan mikroba. Perubahan kandungan senyawa antioksidan flavonoid dan polifenol pada permen hisap ekstrak daun ciplukan merupakan salah satu indikator telah terjadinya kerusakan pada permen hisap. Perubahan tersebut mempengaruhi umur simpan dari permen hisap, dimana semakin lama penyimpanan maka kandungan flavonoid dan polifenol akan semakin menurun. Flavonoid dan polifenol bukan merupakan senyawa yang stabil terhadap pengaruh cahaya, oksigen, suhu dan perubahan kimia, sehingga rentan mengalami oksidasi. Salah satu cara untuk meningkatkan kestabilan senyawa flavonoid dan polifenol yaitu dengan mengubah senyawa tersebut menjadi bentuk glikosida yaitu flavonoid glikosida (flavonoid dengan gula terikat) melalui reaksi transglikosilasi dengan bantuan enzim transferase, maupun sintesis secara kimiawi. Tetapi sintesis secara kimiawi tidak mudah dilakukan karena akan menghasilkan produk dengan konfigurasi a- dan $\beta$ - glikosida (Sulistyo et al,1998). Penurunan kandungan flavonoid dan polifenol diakibatkan oleh terjadinya reaksi oksidasi.

Senyawa flavonoid dan polifenol yang teroksidasi akan mengalami perubahan struktur, yang berupa proses dekomposisi. Pada proses oksidasi senyawa flavonoid maupun polifenol, dimana atom $\mathrm{H}$ pada gugus $\mathrm{OH}$ diambil oleh senyawa pengoksidasi, dengan terurainya struktur maka terjadi perubahan sifat dan fungsinya sebagai bahan aktif akan berkurang bahkan hilang (Kitao dan sekine, 1994). Flavonoid dan polifenol yang mengalami perubahan struktur akan menjadi tidak dikenal sebagai senyawa flavonoid dan polifenol pada hasil analisis kandungan senyawa tersebut, dimana semakin banyak atom $\mathrm{H}$ yang diambil maka semakin kecil kandungan flavonoid dan polifenol yang terukur (Ribereau, 1972). Tingkat ketahanan senyawa flavonoid dan polifenol terhadap kerusakan faktor eksternal, bergantung pada sejauh mana senyawa flavonoid dan polifenol dalam bahan alam memiliki gugus $\mathrm{OH}$ agar setiap senyawa didalamnya dapat berikatan kuat dengan hidrogen sehingga untuk memutuskan ikatan tersebut diperlukan energi yang kuat (Sulaksono dan Syamsudin, 2012).

\section{Kadar air}

Perubahan kadar air pada permen hisap ekstrak daun ciplukan selama penyimpanan dapat dilihat pada Tabel. 2.

Tabel 2. Perubahan Kadar Air pada Kondisi Suhu Ruang $\left(28^{\circ} \mathrm{C}\right)$

\begin{tabular}{cc}
\hline Hari Ke- & Rata-rata Kadar Air (\%) \\
\hline 0 & 2,17 \\
4 & 3,95 \\
8 & 4,87 \\
12 & 5,81 \\
\hline
\end{tabular}


Data pada Tabel 2. menunjukan bahwa selama penyimpanan suhu ruang terjadi peningkatan nilai kadar air. Persamaan regresi untuk kadar air permen hisap ekstrak daun ciplukan, yaitu $y=0,5598 x+4,5013\left(R^{2}=0,9905\right)$ berarti konstanta penurunan mutunya $(k) 0,5598$. Energi aktivasi (Ea) perubahan kadar air yaitu Ea =0,5598 x 1,986(R) kal $/ \mathrm{mol}$ didapatkan Ea sebesar $1,1118 \mathrm{kal} / \mathrm{mol}$ yang artinya untuk memulai terjadinya perubahan kadar air pada permen hisap ekstrak daun ciplukan diperlukan energi sebesar tersebut. Grafik penurunan mutu kadar air dapat dilihat pada Gambar 3.

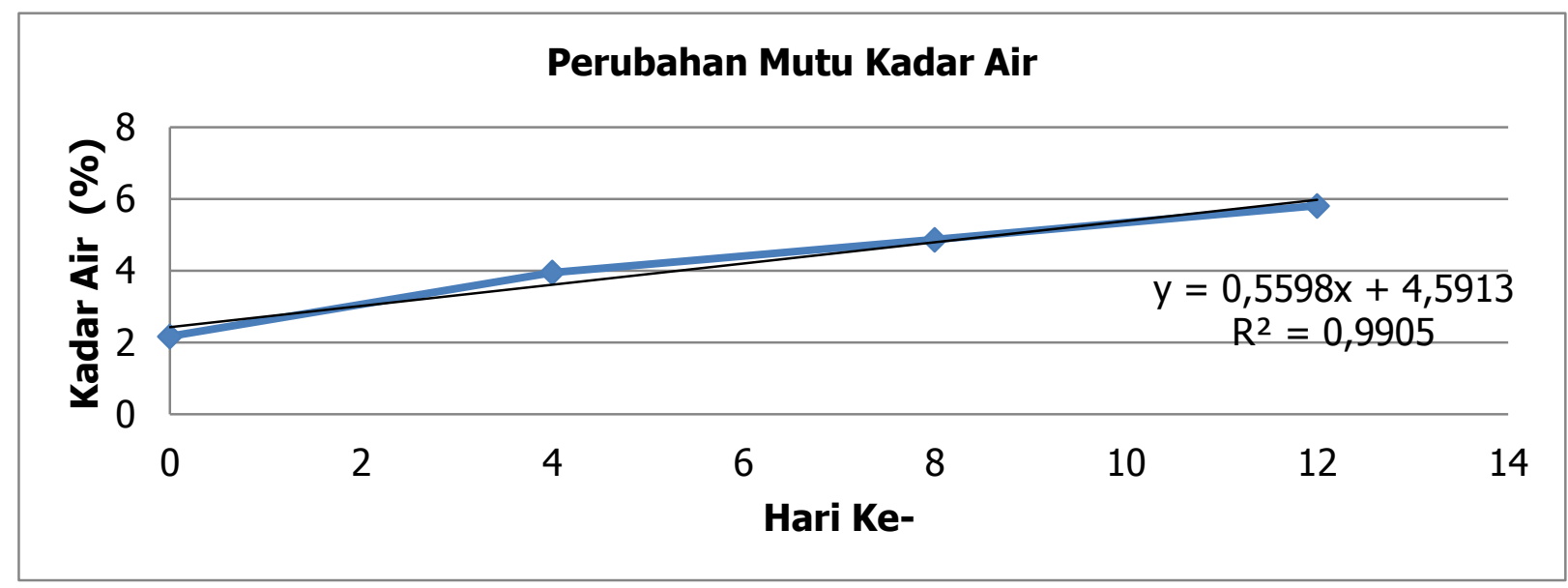

Gambar 3. Grafik Regresi Linier Penurunan Mutu Kadar Air

Kadar air pada permen hisap ekstrak daun ciplukan mengalami perubahan yaitu semakin lama penyimpanan maka kadar air akan semakin meningkat. Kadar air merupakan faktor yang paling berpengaruh pada kemunduran bahan, dimana kemunduran mutu bahan pangan meningkat sejalan dengan meningkatnya kadar air bahan pangan tersebut (Arizka et al, 2014). Produk yang mudah menyerap air bila selama penyimpanan mengalami kontak dengan udara luar yang umumnya untuk lingkungan tropis mempunyai $\mathrm{RH}$ 75-80\%, maka akan mengalami penyerapan uap air yang selanjutnya akan terjadi perubahan fisik (Siswantoro, 2012). Permen hisap ekstrak daun ciplukan mampu meresap air dari udara sehingga produk tersebut dapat disebut sebagai produk yang memiliki sifat higroskopis yaitu mudah menyerap air. Penyerapan air dari udara tersebut akan menyebabkan kadar air dan aktifitas air (aw) bahan meningkat. Berdasarkan teori perubahan fasa dan termodinamika, maka kandungan air dalam bahan pangan yang ditempatkan di udara terbuka akan berubah sampai mencapai kondisi seimbang dengan kelembaban nisbi udara yang bersangkutan. Apabila kadar air bahan cukup tinggi maka sebagian akan berubah menjadi gas kemudian masuk kedalam udara sebagai uap air. Tetapi, apabila kadar air suatu bahan rendah dan udaranya lembab, maka uap air dalam udara akan terserap oleh bahan sehingga kadar air meningkat (Labuza, 1970).

Perubahan kadar air dalam permen hisap ekstrak daun ciplukan dapat dipengaruhi oleh suhu, kelembaban ruang serta lamanya waktu penyimpanan yang menyebabkan terjadinya kerusakan bahan. Kecepatan reaksi yang meningkat akan mempengaruhi kualitas bahan sehingga terjadi penurunan mutu. Peningkatan penyerapan air dari lingkungan (udara) oleh permen hisap akan mempercepat tingkat laju kerusakan produk pangan akibat dari reaksireaksi kimia yang terjadi maupun pertumbuhan jamur yang akan mempengaruhi umur simpan suatu produk pangan. Hal tersebut didukung dengan pernyataan bahwa kelembaban udara ruang penyimpanan yang tinggi, maka dapat terjadi proses absorbsi uap air dari udara yang mengakibatkan peningkatan kadar air (Rentani et al, 2009). 


\section{Umur Simpan}

Umur simpan permen hisap ekstrak daun ciplukan ditentukan berdasarkan peningkatan kadar air selama penyimpanan yaitu 2,17\%, 3,95\%, 4,87\% dan 5,81\%. Berdasarkan perhitungan mutu parameter kadar air, maka dapat ditentukan umur simpan dari permen hisap ekstrak daun ciplukan. Persamaan regresi linier dari kadar air yaitu y $=0,5598 x+4,5013$ dengan nilai $\mathrm{R}^{2}$ sebesar 0,9905 yang sehingga didapatkan konstanta penurunan mutunya $(\mathrm{k})$ 0,5598 . Nilai $k$ dan waktu $(\mathrm{t})$ dari kadar air permen hisap pada suhu penyimpanan ruang $\left(28^{\circ} \mathrm{C}\right)$ dimasukan kedalam persamaan Arrhenius, yaitu $k=k o . e-E / R T$ atau $\ln k=\ln k o-E / R T$. Karena In ko dan -E/R merupakan bilangan konstanta, maka persamaan tersebut dapat ditulis $\ln k=A+B \cdot 1 / T$, sehingga didapatkan persamaan $\ln k=-4,5913-0,5598(1 / T)$. Dengan adanya persamaan tersebut akan diperoleh energi aktivasi yaitu $1,1118 \mathrm{kal} / \mathrm{mol}$. Sehingga nilai konstanta (k) laju penurunan mutu peningkatan kadar air yang didapatkan yaitu 0,01012/hari. Dan dengan menggunakan persamaan $A t=A 0-K$.t maka daya simpan permen hisap ekstrak daun ciplukan berdasarkan nilai kadar air pada suhu ruang yaitu selama 11 bulan. Data perhitungan umur simpan dapat dilihat pada Tabel 3.

Tabel 3. Perhitungan Umur Simpan Permen Hisap Ekstrak Daun Ciplukan

\begin{tabular}{ccccccc}
\hline Parameter & $\begin{array}{c}\text { Persamaan } \\
\text { Arrhenius }\end{array}$ & $\mathbf{R}^{\mathbf{2}}$ & $\begin{array}{c}\text { Energi } \\
\text { Aktivasi } \\
\text { (kal/mol) }\end{array}$ & Nilai k & Suhu & $\begin{array}{c}\text { Umur } \\
\text { Simpan }\end{array}$ \\
\hline Kadar Air & $\begin{array}{c}\text { In } \mathrm{k}=-4,5913 \\
-0,5598(1 / \mathrm{T})\end{array}$ & 0,9905 & 1,1118 & 0,01012 & $28^{\circ} \mathrm{C}$ & 11 Bulan \\
\hline
\end{tabular}

Umur simpan adalah rentang waktu ketika suatu produk pangan tetap aman bila dikonsumsi dengan mempertahankan sifat sensori, kimia, fisik, dan mikrobiologi tertentu, serta sesuai dengan keterangan pelabelan data nutrisi, ketika disimpan pada suatu kondisi. Secara umum, ada tiga macam komponen penting yang berhubungan dengan umur simpan, yaitu perubahan mikrobiologis (terutama untuk produk dengan umur simpan yang pendek), serta perubahan kimia dan sensori (terutama untuk produk dengan waktu simpan menengah hingga lama). Faktor-faktor yang mempengaruhi umur simpan dapat dibagi menjadi dua kategori, yaitu faktor intrinsik dan faktor ekstrinsik. Faktor intrinsik adalah sifat akhir dari produk jadi, yang meliputi aktivitas air $\left(a_{\mathrm{w}}\right), \mathrm{pH}$ dan total asam, potensial redoks $\left(E_{h}\right)$,ketersediaan oksigen, nutrisi, mikrofloraalami,komponen biokimia alami dalam produk (enzim, pereaksi kimia), dan penggunaan pengawet. Faktor ekstrinsik adalah faktor-faktor yang mempengaruhi produk akhir ketika terjadi rantai makanan atau distribusi makanan. Faktor-faktor ekstrinsik selama proses produksi, penyimpanan, dan distribusi makanan terdiri dari pengendalian suhu, kelembaban relatif, paparan cahaya (UV dan infra merah), mikroba disuatu lingkungan, komposisi udara dalam kemasan, perlakuan suhu (contohnya pemanasan kembali atau pemasakan), dan penanganan konsumen (Subarmaniam, 2000).

Permen hisap ekstrak daun ciplukan merupakan produk kering sehingga dengan peningkatan kadar air menyebabkan penurunan kualitas mutu. Kualitas mutu dari permen hisap ditentukan pada beberapa aspek, diantaranya keseragaman bobot, kekerasasan dan waktu larut. Bobot permen hisap yang tidak seragam dapat mempengaruhi jumlah senyawa aktif yang terkandung didalamnya (Farmakope Indonesia, 2014). Syarat kekerasan untuk permen hisap adalah mampu menahan tekanan sebesar $7-14 \mathrm{~kg}$, apabila tingkat kekerasan rendah maka akan menghasilkan permen hisap yang rapuh sehingga mudah hancur dengan waktu larut yang singkat (Hidayati et al, 2010). Permen hisap yang baik memiliki waktu larut selama 5-10 menit (Siregar dan Wirakarsa, 2010). Peningkatan kadar air pada permen hisap 
yang disimpan pada suhu ruang $\left(28^{\circ} \mathrm{C}\right)$ dengan kondisi tanpa dikemas apapun dapat mengakibatkan timbulnya aktifitas mikroorganisme serta meningkatkan terjadinya proses oksidasi sehingga kualitas mutu akan menurun.

\section{KESIMPULAN}

Penurunan mutu pada permen hisap ekstrak daun ciplukan yaitu, semakin lama penyimpanan pada suhu ruang $\left(28^{\circ} \mathrm{C}\right)$, maka semakin menurunnya kandungan senyawa flavonoid dan polifenol, tetapi terjadinya peningkatan kadar air yang dapat mempengarui umur simpan permen hisap ektrak daun ciplukan. Energi aktivasi (Ea) dari perubahan flavonoid dan polifenol sebesar 0,8027 kal $/ \mathrm{mol}$ dan 59,7627 kal/mol serta energi aktivasi (Ea) dari perubahan kadar air sebesar $1,1118 \mathrm{kal} / \mathrm{mol}$. Perhitungan umur simpan didasarkan pada peningkatan nilai kadar air selama penyimpanan, didapatkan bahwa umur simpan permen hisap ekstrak daun ciplukan pada suhu ruang $\left(28^{\circ} \mathrm{C}\right)$ yaitu selama 11 bulan.

\section{UCAPAN TERIMA KASIH}

Terima kasih kami sampaikan kepada Insinas Research Grant dari Kementerian Riset, Teknologi, dan Pendidikan Tinggi Republik Indonesia atas pendanaan studi ini dengan Nomer: 20/P/RPL-LIPI/INSINAS-/III/2018 serta Lembaga Ilmu Pengetahuan Indonesia (LIPI) atas fasilitas yang telah diberikan.

\section{DAFTAR PUSTAKA}

Ahmad, A. R., Juwita, S. A. D. Ratulangi, dan A. Malik. 2014. Penetapan Kadar Fenolik dan Flavonoid Total Ekstrak Metanol Buah dan Daun Patikala (Etlingera elatior (Jack) R.M.SM). Jurnal Pharm Sci Res 2(1): 1-10.

Arizka, A. A. dan J. Daryatmo. 2015. Perubahan dan Kelembaban Kadar Air Selama Penyimpanan pada Suhu dan Kemasan yang Berbeda. Jurnal Aplikasi Teknologi Pangan4(4): 124-129.

Damar, A. C., M. R. J. Runtuwene,dan D. S. Wewengkang. 2014. Kandungan Flavonoid dan Aktivitas Antioksidan Ekstrak Etanol Daun Kayu Kapur (Melanolepsis multiglandulosa Reinch f). Jurnal Ilmiah Farmasi 3(4): 11-21.

Dewanti, N. I. dan F. F. Sofian. 2017. Aktivitas Farmakologi Ekstrak Daun Pandan Wangi (Pandanus amaryllifolius Roxb). Jurnal Farmaka Suplemen15(2): 186-194.

Farmakope Indonesia. 2014. Bahan Tambahan Obat. Edisi Kelima. Departemen Kesehatan Republik Indonesia. Jakarta.

Fitri, N. L.,R. E. Susetyarini,dan L. Waluyo. 2016. Pengaruh Ekstrak Buah Ciplukan (Physalis angulata I.) Terhadap Kadar SGPT dan SGOTMencit Putih Jantan (Mus musculus) Hiperglikemia yang Diinduksi Aloksan sebagai Sumber Belajar Biologi. Jurnal Pendidikan Biologi Indonesia2(2): 180-187.

Haryati, T. Estiasih,dan F. Heppy. 2015. Shelf-life Prediction of Sterilized Mojokerto's Fermented Black Glutinous Rice using Accelerated Shelf-Life Testing (ASLT) Method by Arrhenius Equation Approach. Jurnal Pangan dan Agroindustri3(1): 156-165.

Herawati, H. 2008. Penentuan Umur Simpan pada Produk Pangan. Jurnal Litbang Pertanian27(4): 124-130.

Hermawan, H., Lohita, Bina dan H. Nashiranto. 2018. Kadar Polifenol dan Aktivitas Antioksidan Ekstrak Etil Asetat dan Metanol Buah Ketapang (Terminalia Catappa L.). Jurnal Online Mahasiswa Bidang Farmasil(1):1-8.

Hidayati, N. D., L. S. Marwan,dan Mufrod. 2010. Formulasi Tablet Hisap Ekstrak Etanolik Daun Kemangi (Ocimum sanctum I.) dengan Variasi Pemanis Manitol dan Laktosa. Jurnal IImu Farmmasi dan Farmasi Klinik12(1): 11-19. 
Kitao, S. dan H. Sekine. 1994. A-d-glukosyl Transfer to Phenolic Compounds by Sucrose Phosphorylase from Leuconostoc Mesenteroides and Production of A-arbutin. Biosci, Biotech, Biochem58(1): 38-42.

Labuza, T. P. 1970. Properties of Water as Related to the Keeping Quality of Foods. Proceedings of The Third Internasional Congress of Food ScienceIFT: 618-635.

Luh, N. dan Razimin. 2013. Bawang Dayak Si Umbi Ajaib PenaklukAneka Penyakit. PT Agromedia Pustaka. Jakarta.

Muchtadi, T. R. dan Sugiyono. 2013. Prinsip dan Proses Teknologi Pangan. Alfabeta. Bogor.

Pourmorad, F., S. J. Hossenimehr, dan N. Shahabimajd. 2006. Antioxidant Activity, Phenol and Flavonoid Contents of Some Selected Iranian Medicial Plants. African Journal of Biotechnology5(11): 1142-1145.

Retnani, Y., W. Widiarti, I. Amiroh,L. Herawati, dan K. B. Satoto. 2009. Daya Simpan dan Palatabilitas Wafer Ransum Komplit Pucuk dan Ampas Tebu Untuk Sapi Pedet. Prosiding Media Peternakan32(2): 130-136.

Ribereau, G. 1972. Plant Phenolic. Hafner Publishing Company. New York.

Rohyani, I. S., E. Aryanti, dan Suripto. 2015. Phytochemical Content of Some of Local Plant Species Frequently Used as Raw Materials for Traditional Medicine in Lombok Island. Prosiding Seminar Nasional Masyarakat Biodiversity Indonesia 1(2): 388-391.

Rustini, N. L. dan N. K. Ariati. 2017. Aktivitas Antioksidan dari Ekstrak Etanol Daun Ungu (Graptophyllum Pictum L. Griff). Indonesian E-Journal of Applied Chemistry5(2): 145151.

Singleton, V.L. dan J. A. Rossi. 1965. Colorimetry of Total Phenolics with PhosphomolybdicPhosphotungstic Acid Reagents. American Journal ofEnology and Viticulture16(3): 144-158.

Siregar, C. J. P.dan S. Wikarsa. 2010. Teknologi Farmasi Sediaan Tablet. Penerbit Buku Kedokteran EGC. Jakarta.

Siswantoro, B. Rahardjo,N. Bintoro, dan P. Hastuti. 2012. Pemodelan Matematik Perubahan Parameter Mutu Selama Penyimpanan dan Sorpsi-Isoterm Kerupuk Goreng Pasir. Jurnal Agritech32(3): 265-274.

Solihin, Muhtarudin dan R. Sutrisna. 2015. Pengaruh Lama Penyimpanan Terhadap Kadar Air Kualitas Fisik dan Sebaran Jamur Wafer Limbah Sayuran dan Umbi-Umbian. Jurnal Ilmiah Perternakan Terpadu3(2): 48-54.

Subarmaniam, P. dan K. David. 2000. The Stability and Shelf Life of Food. Woodhead Publishing. UK.

Sudarmadji, S., H. Bambang,dan Suhardi. 2003. Analisa Bahan Makanan dan Pertanian. Liberty. Bogor.

Sulaksono, F. B. dan Syamsudin. 2012. Koreksi Kadar Flavonoid dan Toksisitas dalam Ekstrak Tempuyung (Sonchus Arvensis) dan Pegagan (Centella Asiatica). Jurnal Konversi 1(2): 33-42.

Sulistyo, J.,Y. S. Soeka, dan A. K. Karim. 1998. Sintesis Polifenol-a-Glukosida oleh CG-Tase Secara Reaksi Transglikolisasi. Jurnal Biologi Indonesia2(3): 150- 161.

Syarif, R. dan H. Halid. 1992. Teknologi Penyimpanan Pangan. PAU Pangan dan Gizi. Penerbit ARCAN. Bogor.

Triyono, A., R. Luthfiyanti, T. Rahman,dan N. Y. Pamungkas. 2019. The Effects of Solvents and Maltodextrin on The Characteristics of Physalis Angulata L. Leaf Extract. IOP Conf. Ser.: EarthEnviron. ScI251 (2019) 012030: 1-9.

Winarno, F. G. 2007. Kimia Pangan dan Gizi. PT Gramedia Pustaka Utama. Jakarta.

Winarsi, H. 2007. Antioksidan Alami dan Radikal Bebas. Kanisius. Yogyakarta. 
Zhu, H.,Y. Z. Wang, Y. X. Liu,dan Y. L. Xia. 2009. Analysis of Flavonoids in Portulaca OleraceaL. by UV-VIS Spectrophotometry with Comparative Study on Different Extraction technologies. Food Analytical Methods3(2):90-97. 